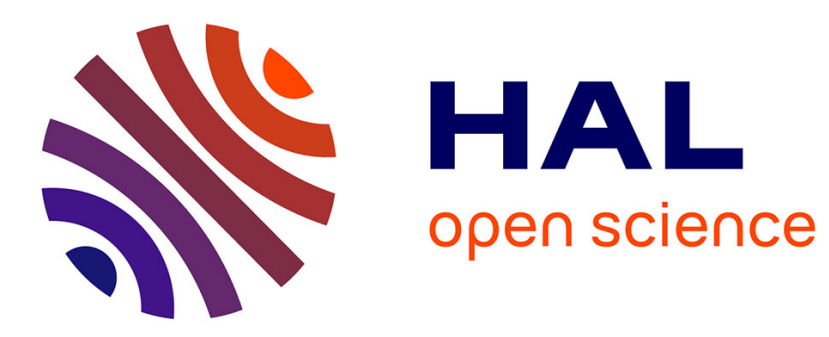

\title{
Excimer lasers in France
}

B. Fontaine

\section{- To cite this version:}

B. Fontaine. Excimer lasers in France. Journal de Physique IV Proceedings, 1994, 04 (C4), pp.C4773-C4-773. 10.1051/jp4:19944213 . jpa-00252680

\section{HAL Id: jpa-00252680 https://hal.science/jpa-00252680}

Submitted on 1 Jan 1994

HAL is a multi-disciplinary open access archive for the deposit and dissemination of scientific research documents, whether they are published or not. The documents may come from teaching and research institutions in France or abroad, or from public or private research centers.
L'archive ouverte pluridisciplinaire HAL, est destinée au dépôt et à la diffusion de documents scientifiques de niveau recherche, publiés ou non, émanant des établissements d'enseignement et de recherche français ou étrangers, des laboratoires publics ou privés. 


\title{
Excimer lasers in France
}

\author{
B.L. FONTAINE
}

GDR 919 du CNRS, Laboratoire J. Valensi, Case 918, 13288 Marseille cedex 09, France

\section{ABSTRACT}

An overview of recent progress in France in physles of excimer lasers and applications of this class of lasers is presented. Particular focus is made on work made in the frame of Eureka Eurolaser Excimer laser program (EU 205). This program, which started in 1987, associates laboratories and industrials from 5 european contries (France, Greece, RFA, Sueden and UK) for research and development on discharge excited excimer lasers and specific applications with the goal to develop a 1-3 $\mathrm{KW}$ average power UV industrial excimer laser. This programm as very recently allowed the achievement in France of a $1 \mathrm{KW}$ average power $\mathrm{XeCl}$ laser $(\lambda=308 \mathrm{~nm})$. Most recent progress achleved on this program in the frame of GDR 919 CNRS "excimer lasers" are reviewed. Emphasis is made on plasma dynamics and discharge stability, atomic and molecular kinetics, laser modeling, optics, fluid-dynamics and coupled phenomena as well as system technical characteristics and performances.

A review of recent work made at GDR 919 CNRS on specific applications of high average power excimer lasers is also presented with a particular focus on material processing (surface hardening, thin films elaboration, microelectronics related processing). The physico-chemical processes inside the plasma plume during thin film elaboration is described in details.

At last, a short description is made of researchs on new methods of rare gas hallde excimer lasers pumping and new promising excimer lasers shemes including active medium excitation by uncoherent light from a sliding discharge on formed ferrite and ionic excimers VUV lasers potentialities. 